\title{
Metal waste management and recycling methods in the nuclear power plant decommissioning and dismantling process
}

Review scientific paper

\author{
Ana Mostečak'; Gordan Bedeković ${ }^{1}$ \\ ${ }^{1}$ University of Zagreb, Faculty of Mining, Geology and Petroleum Engineering, Pierottijeva 6, 10000 Zagreb, Croatia
}

\begin{abstract}
Decommissioning and dismantlement of nuclear power plants (NPP) present the final phase of a nuclear power plant lifetime and are an essential part of an effective nuclear safety culture. While some countries are implementing nuclear exit strategies and others are building new nuclear power plants or prolonging their lifetimes, the decommissioning of facilities is imminent. This paper gives a short overview on decommissioning and dismantling strategies and techniques as an introduction to the applicability of radioactive metal waste recycling and reuse. General estimations suggest that the majority of the waste mass resulting from decommissioning and dismantling is radiologically unrestricted material i.e. exempt waste. The remaining one-third is the radioactive material with different levels of radioactivity. To present radioactive metal scrap recycling in practice, this paper addresses estimations on metal waste amounts resulting from decommissioning, the use of melting as a possible recycling method (with regard to secondary waste generated) and aspects of environmental and health impacts. Additionally, the best practice example of the decommissioning process in a pressurized water reactor (PWR) with NPP technology is given to provide context for the possible future decommissioning of NPP Krško. After consideration of the available data on decommissioning waste management, the conclusion is that while the decision on decommissioning strategies and technologies is not straightforward but unique to each country, current experiences give important context to the complexity and potential of decommissioning and provide a basis for future actions.
\end{abstract}

\section{Keywords}

nuclear power plants, decommissioning and dismantling, metal recycling, waste management.

\section{Introduction}

In the context of sustainable development, environmental protection, and energy supply security, nuclear fission technology often faces certain opposition. Consequently, management of waste deriving from nuclear facilities and their operation is an equally complex topic, if not more so. The global climate change challenge casts a different light on the role of nuclear energy compared to other energy sources. Work from Truelove and Greenberg (2013) discusses the connection between climate change and US citizen's openness to the use of nuclear power. Their study focuses on variables affecting whether participants' opinions on nuclear energy are influenced by their concerns about global climate change. Around $35 \%$ of survey participants stated that climate change related concerns did make them more open to considering nuclear energy use as an energy source (Truelove and Greenberg, 2013). Additionally, results from the study provide a baseline for the comparison of US citizen perceptions, especially in the context of the Fukushima Daiichi nuclear power plant (NPP)

Corresponding author: Ana Mostečak

ana.mostecak@gmail.com accident. Data available from World-nuclear (2017) shows global decommissioning trends. An update from December 2016 lists decommissioned reactors where 11 reactors have been closed following damage in an accident or serious incident, 27 reactors have been closed prematurely by political decision or consideration, and 113 reactors have been closed having fulfilled their purpose or being no longer economical to run. Considerable experience results from decommissioning various types of nuclear facilities with numerous power reactors (including experimental and prototype units) and at least 15 being fully dismantled. According to the International Atomic Energy Agency (IAEA) (as quoted in Samseth, 2012) the average lifespan of a civilian nuclear reactor is 27 years, with many having their licenses renewed and operating beyond their original design life. However, many first generation reactors are reaching the end of their original design lives. Goodfellow et al. (2011) mention that, even after the Fukushima accident, countries worldwide are investing in or considering building new nuclear power plants, where this new-build activity is termed "nuclear renaissance".

Considering both the so-called nuclear renaissance and decommissioning trends, it is certain that any devel- 
opment scenarios of NPP decommissioning and dismantling activities present a crucial and essential part of an effective nuclear safety culture. Additionally, imminent decommissioning and dismantling will result in significant amounts of waste materials where recycling and reuse could prove beneficial in the long run. The aim of this paper is to present a short overview of decommissioning and dismantling strategies and techniques as an introduction to the applicability of radioactive metal waste recycling and reuse. To provide a practical context for the information presented, the final chapter gives a concise summary of the decommissioning process of an NPP with pressurized water reactor (PWR) technology. PWR technology was chosen to illustrate possibilities for decommissioning, which can also be applied to NPP Krško.

\section{Issues and Strategies of Decommissioning and Dismantling}

Nuclear design plays a vital role not just in the operational part of an NPP lifetime, but also in an NPP end-oflife. Babilas and Brendebach (2015) state that plants are built for the safe and economical production of electricity but rarely for easy decommissioning which is particularly the case for older first generation reactors. While decommissioning is a unique process for each facility, due to gained experience it is becoming more feasible. Babilas and Brendebach (2015) define decommissioning as a process that involves decontamination, dismantling and waste management procedures. In the same article, they discuss general approaches for the selection and evaluation process of decontamination and dismantling techniques (D\&D) applicable for a particular site or structure, system, and component (SSC). Some of the factors essential for the selection of D\&D techniques and decision-making are radiation protection aspects, aspects of safety, the infrastructure needed, decontamination/dismantling capacity, aspects of costs, generation of radioactive waste, de-installation/maintenance time, etc. (Babilas and Brendebach, 2015). In decommissioning, buildings and structures are removed, as well as parts in the proximity of the reactor core and construction materials (mostly steel and concrete). Depending on the decommissioning type, materials are packed, transported and safely disposed of. According to data available from United Nations Environment Programme Year Book (Samseth, 2012) around 68\% of the waste mass resulting from decommissioning is radiologically unrestricted material while the rest is the radioactive material with different levels of radioactivity. Radiologically unrestricted material is also referred to as exempt waste (EW) which meets the criteria to be released from regulatory control, respecting exemption and radiation protection principles (IAEA, 2007).

There are three accepted approaches to decommissioning: immediate dismantling, deferred dismantling, and entombment (Samseth, 2012). In immediate dismantling (known as DECON) all radioactive SSCs of the facility are removed or decontaminated in order to allow for unrestricted use of the site. Deferred dismantling (known as "safe enclosure" or SAFESTOR) includes removal of spent nuclear fuel (SNF) ensuring the safety of the facility but leaving dismantling for future activities. If after removal of SNF, the reactor is encased in a durable material with the aim of leaving it until its radioactivity decreases, we are talking about entombment which is very complex and only done in specific cases. Decommissioning approaches require different standards of worker safety and result in different amounts of potentially valuable resources available. In the context of exposure rates, entombment enables less contact with the waste i.e. less exposure to radioactivity while deferred dismantling assures some of the radioactivity to decrease before taking actions. In immediate dismantling, the safety standards are more rigorous and due to the immediate actions, more material is classified as radioactive. Deferral periods can affect some materials and decrease their availability for reuse and recycling.

Waste resulting from D\&D can be classified into four categories: very low level (VLL), low level (LL), intermediate level (ILW) and high level waste (HLW). While there are some differences in the national waste classifications systems, the IAEA classification system puts an emphasis on the aspect of disposal safety. According to the IAEA (2007, 2009), HLW has specific radiological characteristics: it includes long lived radionuclides, it generates significant amounts of heat and is associated with spent fuel, fuel reprocessing waste streams and other waste with similar radiological properties. These specific characteristics need to be considered in choosing the disposal strategies and generally deep geological disposal is required (IAEA, 2009). In IAEA's classification, radiological characteristics of ILW still require isolation and containment due to the presence of long lived radionuclides, but with considerably lower heat dissipation present. The activity concentrations do not allow for near surface disposal so disposal at greater depths is necessary (IAEA, 2009). LLW covers a range of waste, either with limited amounts of long lived radionuclides or higher activity concentrations of short lived ones. For LLW, isolation and containment is required, however it can still be disposed of in the near surface facilities (IAEA, 2009). While VLLW does not meet the criteria to be considered EW, there are no requirements for isolation and containment so VLLW can be disposed of in the near surface facilities, including those with limited regulatory control (IAEA, 2009). Decommissioning generates around two-thirds of total VLLW, LLW and ILW produced during a plant's lifetime alone (Samseth, 2012). HLW is the smallest in volume but contains $95 \%$ of the overall radioactivity of the waste produced and mainly consists of SNF, while in dismantling, reactor components are the most radioactive (Samseth, 2012). 
In their work, "Fernald's dilemma: recycle the radioactively contaminated scrap metal, or bury it?" Yuracko et al. (1997) discuss radioactive scrap metal (RSM) as a possible plug to a leak in the material cycle of nuclear activities i.e. activities of the Fernald uranium processing facility. The suggestion is to melt metals present at the site to produce containers for the transport and disposal of LLW. The article compares the cost and benefits of such activities and addresses potential health and safety risks. The authors propose a two-phase decision methodology where phase one is a life-cycle analysis assessing the possible impacts of management alternatives for RSM and phase two is the decision phase. As with any activities related to nuclear technology, certain public opposition is present. Nives et al. (1998) mention that in this context, the questions of the choice between recycling or disposing of RSM is not just an issue of having a metal supply that is clean versus having one that is radioactive. The extent of public acceptance, again as in any nuclear technology related matter, depends on the quality of the regulatory process and provision of the information regarding risks (Nieves et al, 1998).

In recycling, the separation of radioactive and nonradioactive materials is essential to the minimization of the waste generated. Additionally, it maximizes the ability of material reuse and recycling, but at the same time, worker exposure needs to be taken into account (Samseth, 2012). Hrncir et al. (2013) discuss scenarios of the recycling of radioactive steel within nuclear and civil engineering industries from the radiation protection aspect and derive clearance levels for analyzed radionuclides i.e. the maximum specific mass activity of material allowing its recycling/clearance. They mention that clearing as much as possible of materials from decommissioning is beneficial, not only that it saves potentially valuable raw material, but it also increases the repository capacity and saves financial funds that would otherwise be spent on treatment and disposal. A detailed overview of the feasibility and effectiveness of recycling of what is termed as disaster waste is given in the work of Brown and Milke (2016), focusing on mostly natural disasters but including the tsunami that led to the Fukushima Daiichi NPP accident. A decision on decommissioning waste management is usually not plainly straightforward and requires careful analysis of timing, funding, regulatory framework, available personnel, future use of the location, etc. The work from Sanders and Sanders (2016) discusses nuclear waste management strategies in the Western European Nation States. They conclude that in order to ensure a stable outcome "each nation state must look outward to its shared international obligations, but there must also be an inward reflection of a nation state to its own traditions, customs, and legal/law making regimes" (Sanders and Sanders, 2016, p.69). A similar approach applies to the management of the decommissioning waste. The next chapter covers the recy- cling of radioactive metal scrap as one of the possible methods of waste management.

\section{Radioactive Metal Scrap Recycling Practices}

A detailed analysis of disposition alternatives for radioactive scrap metal (RSM) is given in Nieves et al. (1998). Nuclear power plants are mentioned as one of the largest sources of RSM and a rare beneficiary of recycled radioactively contaminated metal. Estimated amounts of metal available and their majorly low level radioactivity suggest consideration of its future applicability.

Table 1: Estimated nuclear power plant scrap metal mass by activity category, metal type, and geographical region (in 1000 tons) (from Nieves et al., 1998)

\begin{tabular}{|c|c|c|c|}
\hline Region/ Activity & Copper & $\begin{array}{c}\text { Iron } \\
\text { and steel }\end{array}$ & $\begin{array}{c}\text { Stainless } \\
\text { steel }\end{array}$ \\
\hline & $10^{3} \mathrm{t}$ & $10^{3} \mathrm{t}$ & $10^{3} \mathrm{t}$ \\
\hline \multicolumn{4}{|l|}{ North America } \\
\hline Suspect radioactive & 669 & 1025 & 6 \\
\hline $\begin{array}{l}\text { Surface contaminated } \\
\text { - removable }\end{array}$ & 11 & 902 & 136 \\
\hline Total & 680 & 1927 & 142 \\
\hline \multicolumn{4}{|l|}{ Europe } \\
\hline Suspect radioactive & 771 & 1693 & 4 \\
\hline $\begin{array}{l}\text { Surface contaminated } \\
\text { - removable }\end{array}$ & 13 & 1128 & 183 \\
\hline Total & 784 & 2821 & 187 \\
\hline \multicolumn{4}{|l|}{$\begin{array}{l}\text { Russian Federation } \\
\text { (former SSSR) }\end{array}$} \\
\hline Suspect radioactive & 324 & 1285 & 0 \\
\hline $\begin{array}{l}\text { Surface contaminated } \\
\text { - removable }\end{array}$ & 5 & 480 & 173 \\
\hline Total & 329 & 1765 & 173 \\
\hline \multicolumn{4}{|l|}{ Asia } \\
\hline Suspect radioactive & 335 & 478 & 2 \\
\hline $\begin{array}{l}\text { Surface contaminated } \\
\text { - removable }\end{array}$ & 5 & 456 & 61 \\
\hline Total & 340 & 934 & 63 \\
\hline \multicolumn{4}{|l|}{ Rest of the world } \\
\hline Suspect radioactive & 40 & 82 & 1 \\
\hline $\begin{array}{l}\text { Surface contaminated } \\
\text { - removable }\end{array}$ & 1 & 55 & 12 \\
\hline Total & 41 & 137 & 13 \\
\hline \multicolumn{4}{|l|}{ World total } \\
\hline Suspect radioactive & 2139 & 4563 & 13 \\
\hline $\begin{array}{l}\text { Surface contaminated } \\
\text { - removable }\end{array}$ & 35 & 3021 & 565 \\
\hline Total* & 2174 & 7584 & 578 \\
\hline
\end{tabular}

*totals may not add because of rounding 
Table 2: Projected annual average releases of RSM from NPP for the period of $2010-2043$, in 1000 tons (from Nieves et al., 1998)

\begin{tabular}{|l|c|c|c|}
\hline \multirow{2}{*}{ Region } & Copper & $\begin{array}{c}\text { Iron } \\
\text { and steel }\end{array}$ & $\begin{array}{c}\text { Stainless } \\
\text { steel }\end{array}$ \\
\cline { 2 - 4 } & $10^{3} \mathrm{t}$ & $10^{3} \mathrm{t}$ & $10^{3} \mathrm{t}$ \\
\hline North America & 20,6 & 58,4 & 4,3 \\
\hline Europe & 23,8 & 85,5 & 5,6 \\
\hline $\begin{array}{l}\text { Russian Federation } \\
\text { (former SSSR) }\end{array}$ & 10,0 & 53,5 & 5,2 \\
\hline Asia & 10,3 & 28,3 & 1,9 \\
\hline Rest of the world & 1,2 & 4,2 & 0,4 \\
\hline Total* & 65,9 & 229,8 & 17,5 \\
\hline
\end{tabular}

*totals may not add because of rounding

Regulation practices are based on guidelines from the International Commission on Radiological Protection (ICRP) that can be summarized in three principles:

1) before any action that may include radiation exposure, there must be a justification of it providing greater benefit than harm;

2) to evaluate practice in this sense, all of its aspects need to be considered, and not only radiological protection; there must be equity in risk distribution, and radiation doses need to be kept as low as possible;

3) individual risk must be controlled and kept at a level, so it does not require further regulatory actions (ICRP as quoted in Nieves et al., 1998).

The article presents potential scrap inventory from world nuclear power plants for plants listed as under construction or completed by 1993 and only includes reactors above 100MWe (Nieves et al., 1998). For an estimation of available annual amounts of nuclear power plant scrap, it is assumed RSM will be available 50 years from start-up. Table 1 shows mass estimates for copper, iron and steel and stainless steel, in geographic regions for material categories of suspected radioactivity and of removable surface contamination. Additional quantities might be available in the context of storage that allows for radioactive decay (Nieves et al., 1998). Although estimations include only reactors up to 1993 , it is still a valuable and highly illustrative piece of information regarding the potential of RSM recycling and reuse. Table 2 shows projected annual average RSM release from NPP over the period from 2010 to 2043. According to the authors, considering possible health and environmental stressors, recycling of RSM as a practice is justified. The health and environmental impacts are considered to be almost half of those for disposal and replacement, and environmental impacts orders of lower magnitude. Additionally, the authors suggest that the principles of radiological protection can be optimized by using a tiered system of release criteria for the exempt waste. For socio-economic parameters, a comparison of the results was more complicated considering the possible public opposition to RSM recycling. The authors conclude that this aspect could be greatly facilitated by "the quality of the regulatory practice and the provision of information regarding comparative risks of the RSM management alternatives" (Nieves et al., 1998, p.1101).

Regarding metal recycling methods, Slimak and Nečas (2016) present melting as a suitable method for metal recycling and decontamination. The method includes exposing scrap metal to high temperatures and heating it above its melting temperature. During exposure, elements and their radioisotopes are redistributed from metal to slag and dust/fumes. The distribution of contaminants depends on the elemental properties (e.g. chemical composition, the solubility of an element in the molten metal, the density of oxides, etc.) and furnace properties (e.g. melting temperature and furnace type) (Min et al. 2009 as quoted in Slimak \& Nečas, 2016). Elements chemically similar to iron will remain within the melt while more volatile elements will be transferred to off-gases and slag. Adequate air protection is necessary, in the form of highly efficient air filtration systems.

The melting method requires a melting facility and a procedure involving several steps. Firstly, metal needs to be sorted and fragmented, possibly decontaminated (to increase the amount of metal to be recovered). Metals with different properties (e.g. ferrous metals and copper) need to be separated before treatment. Scrap metal type and radiological characteristics determine the method of its fragmentation (i.e. thermal or mechanical) in order to get fragments of a pre-determined size (Slimak and Nečas, 2016). There are two important aspects of RSM melting that influence the affordability and applicability of the method: estimation of amounts of waste resulting from decommissioning that is suitable for melting and amounts of secondary radioactive waste (RAW) generated.

An example of a method for calculating quantities of contaminated metal appropriate for melting treatment is the OMEGA code, explained in more detail in the article from Slimak and Nečas (2016). According to Slimak and Nečas, secondary RAW is generated in the form of slag, dust, furnace lining, spent filters, etc. Metal melting results in secondary RAW amounting to $2-5 \%$ (by weight) of the original amount of scrap metal. Estimated amounts of secondary RAW arising from melting during one year are $10-40$ tons of slag, 0.1 ton of dust and 8.2 -10.6 furnace lining. It is important to mention that estimations result from assumptions depending on the type of furnace and lining. Secondary RAW generated from the treatment needs to be packed and adequately disposed of. Waste is packed into drums and transported to a processing facility where it is treated, conditioned and packed before being transported for disposal at the national radioactive waste repository (Slimak and Nečas, 2016). In Slovakian context discussed by Slimak and 
Nečas (2016), the repository is intended for disposal of LLW. Therefore, secondary RAW must meet the acceptance limits for disposal, i.e., criteria for LLW before being disposed of.

The advantages of metal decontamination by melting are related to it being a proven technology and resulting in significant waste volume reduction where the final product in the form of ingot is homogenous with activity bound in the metal that can be precisely determined and the possibility of keeping ingots until their radioactivity decreases to desired levels (Slimak and Nečas, 2016).

Work from Hrncir and Necas (2013) gives an example of the practical use of RSM. The authors developed a methodology for the reuse of VLL radioactive material and described radiation impact assessment for the motorway tunnel scenario. For this model, data from a real two-tubed tunnel was used (radius $\approx 5.5 \mathrm{~m}$ and the total length of both tubes $2 \mathrm{~km}$ ). Reinforcing components were made from VLL radioactive steel: bars bound together in a reinforcement cage of the strip foundations in the secondary lining and for two layers of steel reinforcing mesh in the primary lining, details on radiation impact assessment are available in Hrncir and Necas (2013). Tatranský and Nečas (2009) present a method of using metals contaminated by radionuclides with a relatively short half-life for a particular industrial purpose, i.e., conditional release of metals into the form of steel railway tracks.

Several authors discuss methods of cutting operations in dismantling, Bonavigo et al. (2010) measure the spreading of radioactive contamination during dismantling presented on the example of Italian NPP (thermal cutting of the primary circuit). The authors present time and dust production data for two thermal cutting methods: plasma cutting and oxy-fuel cutting, and recognize metal aerosol and dust resulting from thermal cutting as a matter significant for further research. Regarding contamination, the authors conclude that sufficient worker safety and environmental protection can be ensured by the use of "individual radioprotection devices and devices for the protection of the respiratory track, such as emissions retaining rooms, filtering systems, masks, gloves and suits" (Bonavigo et al., 2010, p.365). Another experience in dismantling is given in Cesari et al. (2008) where cutting methods are compared, and chemical composition of dust i.e. the relation between technical parameters and emission composition is discussed. Methods used in the comparison are thermal methods (plasma cutting any oxy-fuel cutting). The chemical composition of the dust focused on samples containing elements ( $\mathrm{Mn}, \mathrm{Ni}, \mathrm{Zn}, \mathrm{Ca}, \mathrm{Cu}, \mathrm{Pb}$, and $\mathrm{Cr}$ ) and mixtures (NOx and VOS). Plasma cutting generally resulted in higher cutting temperatures and 2 to 5 times larger amounts of pollutant produced than oxy-fuel cutting (Cesari et al., 2008).

Environmental and health impacts and risks associated with RSM recycling and reuse need to be closely monitored and considered in decision-making. According to Nieves et al. (1998), both the recycling and the disposal alternatives for RSM management involve environmental and health risks (e.g. radiological and chemical exposures of workers and the public, transportation accidents, impact on water and air quality, etc.). Detailed information on radiation impacts is offered in Slimak and Nečas (2016) where exposure pathways in certain working scenarios are discussed. The selected scenarios combine radiation exposure pathways with regard to specific exposure conditions and the occupational area geometry. The three main exposure pathways were external exposure, inhalation, and ingestion. All pathways were not used for every working scenario. The scenario for a furnace operator was based only on external exposure as the main pathway, considering the furnace room as a separate and closed object. For the slag workers, exposure was dependent on the slag removing method, either manually (external and inhalation) or by using a customized manipulator (only external exposure). All three pathways are relevant for the working scenario for the ingot castor and the ingot handler, as well as for the scenario in which repair of the furnace is required. For workers in the transport and storage activities, external exposure was considered as the most relevant. The individual effective dose (IED) for workers was used to compare proposed scenarios. The authors concluded that the highest IED was associated with the slag manipulation scenario. The least concerning option in this scenario was the one where slag removal was done by using a manipulator. In this scenario, the annual received IED would not exceed the maximum allowed dose limits set by Slovakian legislation (Slimak and Nečas, 2016).

One method of addressing environmental and health risks is the use of clearance levels. As defined in the IAEA Safety Glossary, clearance levels are values of activity concentration or total concentration, usually set by the regulatory body, at which or below which the source of radiation can be released from the regulatory control (IAEA, 2007). Determining clearance levels for radioactive scrap metals is essential for its potential recycling and reuse. Unconditional clearance (UC) allows for any possible use of material. Dose constraint (DC) definition differs for different types of exposure (e.g. medical, occupational, public, etc.) but as a general term it refers to a "restriction in the individual dose delivered by a source which serves as an upper bound on the dose" (IAEA, 2007, p.59). For the clearance of radioactive materials dose, DC values are used to ensure radiation protection of the public. In the context of public exposure, DC refers to "an upper bound on the annual doses that members of the public should receive from the planned operation of any controlled source" (IAEA, 2007, p.59). Since a considerable amount of RSM contains the concentration of radionuclides only slightly above the legislative limits for UC into the environment, environmental 
and economic incentives exist to maximize the utilization of releasing concepts (IAEA as quoted in Hrncir and Necas, 2013). Conditional clearance needs to meet health and environmental protections standards. Hrncir et al. (2013) provide detailed steps for determining conditional clearance levels for several radionuclides. An article by Wei et al. (2009) gives an overview of the clearance measurement of metal scraps for a nuclear facility in Taiwan where VLL radioactivity waste was sampled and analyzed. The authors recognized recycling and reuse as cost-effective, saving resources and storage volume necessary for disposal, and mention the importance of adequate technical capabilities (establishing a verified measurement system, a program of quality assurance and the development of procedures for radionuclides that are hard to measure) (Wei et al., 2009).

An example of cost-benefit analysis and costs aspect of metal recycling is available in Slimak and Nečas (2016) where the use of a melting method as a part of the waste management strategy is roughly estimated to possibly save 17 million $€$. The authors provide this as a rough estimation that can vary depending on factors like money value, labor costs, storage costs, etc. The estimation was derived by comparing two scenarios for the case of decommissioning two NPPs, currently used waste management of the metals and the scenario including the use of the melting method. In the first scenario, total costs took into consideration costs of activities like fragmentation, decontamination, treatment, release and disposal of RAW, but not costs for the dismantling of the technological components (Slimak and Nečas, 2016).

The market impact of RSM recycling and reuse are mentioned in Nieves et al. (1998) where market analysis and data are presented (e.g. a suggestion that the market impact of recycling iron and steel would be minimal).

\section{Example of the decommissioning process in a PWR Nuclear Power Plant}

The Nuclear power plant Stade was the first German commercial nuclear power station to use PWR technology. When it was commissioned in 1972, it was ranked as Germany's highest-output PWR NPP with the net installed capacity of $630 \mathrm{MW}$. In 1984, Stade started to cogenerate process heat which is supplied to neighbouring salt works that raised its overall efficiency (Kernkraftwerk Stade, 2004). It was decommissioned in 2003 (with dismantling starting in 2005), for economic reasons. Its electric output was half of most other German NPP but with equal or higher expenses of operating. Additionally, residual generation quota proposed under Germany's nuclear exit strategy would have been exceeded in 2004, so its lifetime was cut short by one year.

Due to the structural design of the facility in PWR technology, where only the reactor building and the reactor auxiliary building are in the radiation control area,

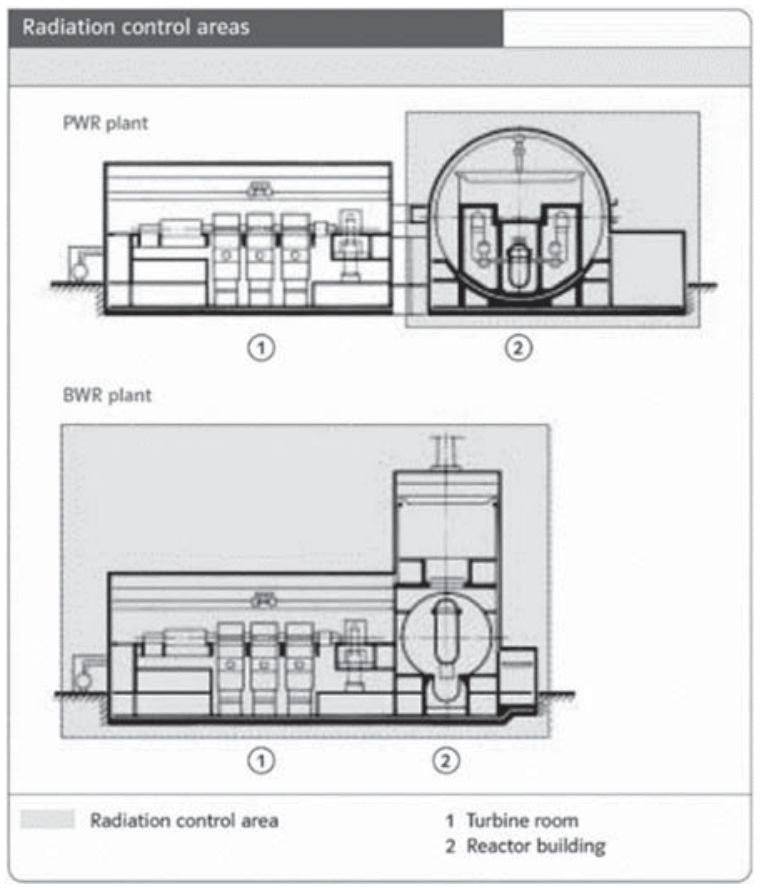

Figure 1: Comparison of the PWR and BWR reactor types (from Kernkraftwerk Stade, 2004)

handling of turbine parts is easier since the turbines and the generator are located outside of this area, unlike in the case of a boiling water reactor (BWR). Figure 1 compares PWR and BWR facility designs (Kernkraftwerk Stade, 2004).

The decommissioning of the NPP Stade is one of the best practice examples in decommissioning performed by the company E. ON New Build \& Technology GmbH (Ehlert, 2012). Prior to the dismantlement, there was a transition phase (around one and a half years) in the NPP Stade to ensure its safe and efficient transfer from fullload operation to dismantlement while dismantlement of the NPP was done in four phases (Kernkraftwerk Stade, 2004). A detailed timeline of all the phases in the decommissioning of the NPP Stade is shown in Figure 2 (Ehlert, 2012).

During the first dismantlement phase, logistics systems are set within the radiation control area, and the dismantlement of larger plant components is planned. Dismantlement Phase I includes the removal of the flood tanks in the primary circuit, the control rod assembly and the pressurized emergency cooling tanks and other nuclear-contaminated systems. Where possible, extra space is created for easier managing. The second phase deals with large components (from the primary coolant pipe system) and preparatory work preceding actual removal and dismantlement. In the third dismantlement phase, most of the radioactive NPP parts are removed (reactor pressure vessel - RPV, concrete shielding enclosing the RPV, overhead concrete slab shielding the reactor room, fuel racks in the former fuel storage tank and other RPV components). Strategies and solutions for 


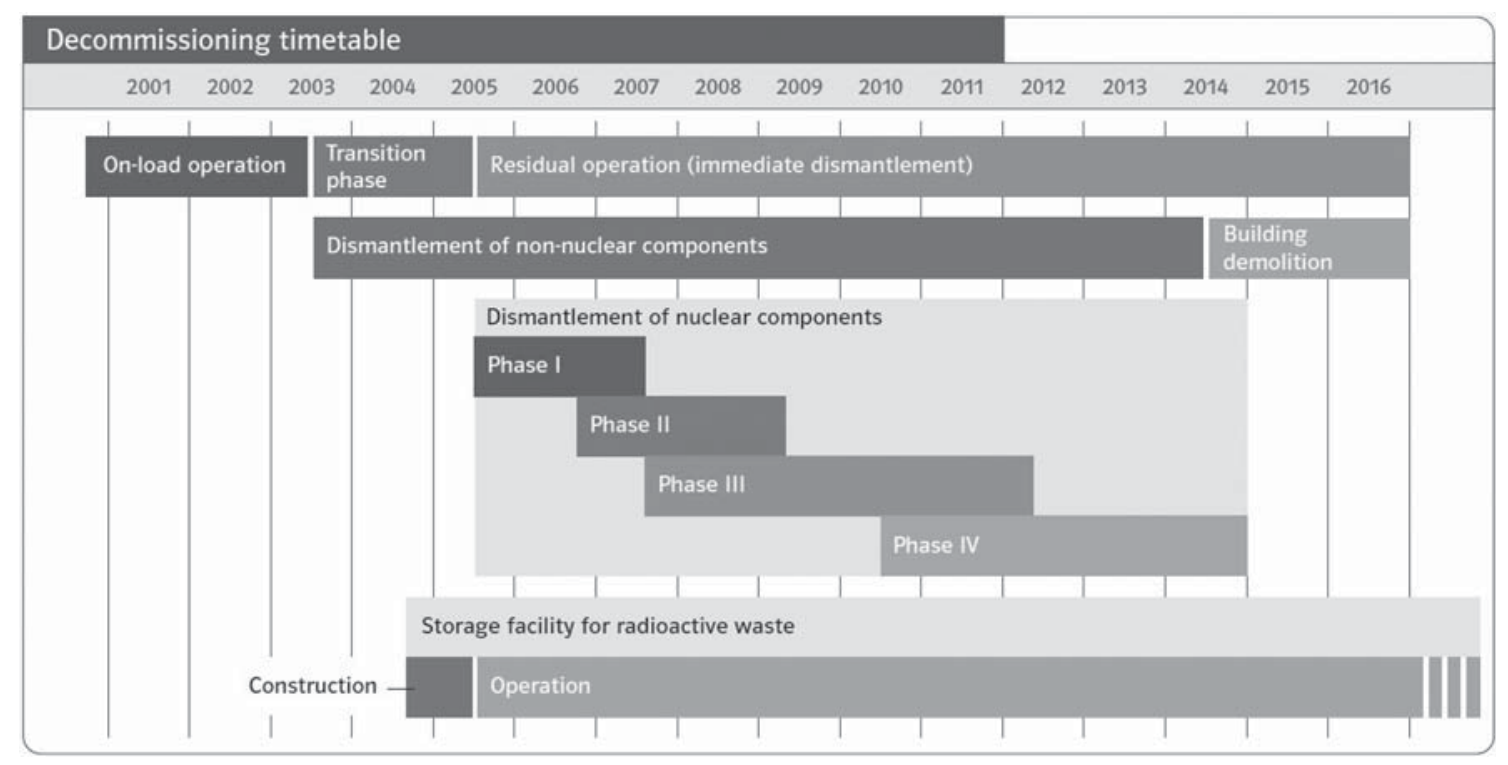

Figure 2: Decommissioning timeframe (from Kernkraftwerk Stade, 2004)

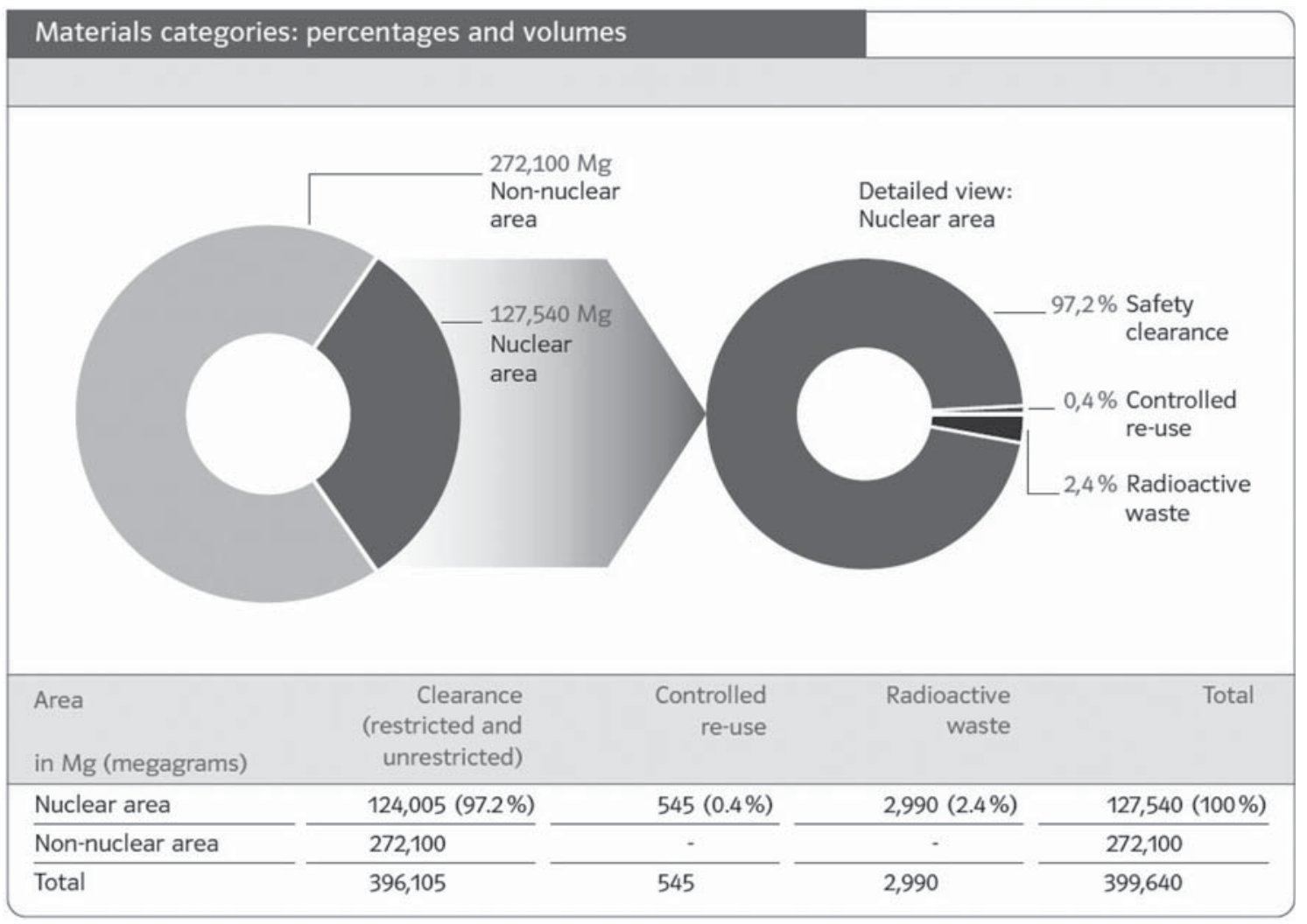

Figure 3: Diagram of the waste generated through decommissioning at the NPP Stade (from Kernkraftwerk Stade, 2004)

the removal of RPV in a PWR are given by Maggini et al. (2016). In the final stage of dismantlement, all remaining systems from the radiation control area are removed, and lastly water purification and ventilation plants. Building structures are decontaminated until they meet the clearance requirements. The final stage is considered finished only after site can be released from the nuclear facility control and permit regime. The immedi- ate dismantling approach, used in the NPP Stade, is the preferred strategy used in Germany (Ehlert, 2012). Besides dealing with critical paths and logic, the phase approach used relates to the specifications of German licensing and its unique regulatory system and administration. Figure 3 shows the waste resulting from the decommissioning process at the NPP Stade (Kernkraftwerk Stade, 2004). 
Although the majority of the material resulting from the dismantlement process is not contaminated, it still has to be tested before being treated as normal waste. After measurements, materials are sent to final clearance testing or need to undergo decontamination which is an important process resulting in a decrease in secondary waste volume. In cases of a surface contamination, decontamination methods used in the example of the NPP Stade are steel grit blasting, water blasting, and chemical flushing (Kernkraftwerk Stade, 2004). Due to the type of materials in question, the clearance process is completed when, after the final clearance testing, the regulatory body gives its final approval. Material in the controlled re-use category makes a small portion of the total waste generated. Radioactive waste from the NPP Stade was disposed of according to standards required for the final storage.

It is worth mentioning that in the work from Slimak and Nečas (2016), the melting method for the recycling of RSM is presented based on the decommissioning of two Slovakian NPPs where one is a V1 NPP (a Russian type of PWR) which gives practical context for the applicability of this method.

\section{Conclusion}

Existing trends in nuclear energy use are reflected by countries proposing and implementing nuclear-exit strategies and others planning to build new or prolong the lifetimes of their nuclear power plants. In both scenarios, decommissioning and dismantlement as its final phase in the shutdown of NPPs is imminent and presents a complex process where decision-making should be done on a multidisciplinary basis. All decisions must consider environmental and radiation protection aspects, as well as the overall financial aspect of the selected decommissioning strategy.

As seen from the data presented in this paper, the decommissioning of an NPP generates significant amounts of waste, especially scrap metal waste whose recycling presents an important method of managing waste by saving both disposal storage resources and financial funds but needs to include careful analysis of technical feasibility, economic value and safety standards. While decommissioning is certain for any NPP at its end of life, the decision on decommissioning strategies and technologies is unique to each country. However, the available experience and methods developed provide a useful first step to build upon. Considering the approaching end of life for the NPP Krško, which is a PWR technology reactor with a similar capacity as the one in the NPP Stade, RSM amounts available from decommissioning, recycling methods, and experiences presented in this paper show both the complexity and the potential of the decommissioning process and could provide guidelines once the decision for the decommissioning and dismantlement process is made.

\section{References}

Babilas, E., \& Brendebach, B. (2015): Selection and evaluation of decontamination and dismantling techniques for decommissioning of large NPPs components. Progress in Nuclear Energy, 84, 108-115. http://doi.org/10.1016/j. pnucene.2014.09.005

Bonavigo, L., De Salve, M., Zucchetti, M., \& Annunziata, D. (2010): Radioactivity release and dust production during the cutting of the primary circuit of a nuclear power plant: The case of E. Fermi NPP. Progress in Nuclear Energy, 52(4), 359-366. https://doi.org/10.1016/j.pnucene. 2009.07.009

Brown, C., \& Milke, M. (2016): Recycling disaster waste: Feasibility, method and effectiveness. Resources, Conservation and Recycling, 106, 21-32. https://doi.org/10.1016/ j.resconrec.2015.10.021

Cesari, F. G., Rogante, M., \& Giostri, A. (2008): Results of the experimental campaign on contaminated metal components parameters and suggestions for safely NPP component dismantling. Nuclear Engineering and Design, 238(10), 2801-2810. https://doi.org/10.1016/j.nucengdes. 2008.05.009

Ehlert, A. (2012): Best Practice in E.ON Decommissioning Projects. Available at: https://www.iaea.org/OurWork/ST/ NE/NEFW/WTS-Networks/IDN/idnfiles/WkpPlanLicencingDecomProjetc_Germany2012/WkpPlanLicencingDecomProjetc_Germany2012-Best_practice_EON_decomEhlert.pdf [Äccessed 24.01.2017]

Goodfellow, M.J., Williams, H.R., \& Azapagic, A. (2011): Nuclear renaissance, public perception and design criteria: An exploratory review. Energy Policy, 39(10), 6199-6210. http://doi.org/10.1016/j.enpol.2011.06.068

Hrncir, T., Panik, M., Ondra, F., \& Necas, V. (2013): The impact of radioactive steel recycling on the public and professionals. Journal of Hazardous Materials, 254-255(1), 98-106. https://doi.org/10.1016/j.jhazmat.2013.03.038

Hrncir, T., \& Necas, V. (2013): Recycling and reuse of very low level radioactive steel in motorway tunnel scenario. Nuclear Engineering and Design, 265, 534-541. https:// doi.org/10.1016/j.nucengdes.2013.06.029

International Atomic Energy Agency. (2007): IAEA Safety Glossary Terminology Used in Nuclear Safety and Radiation Protection. Available at: http://www-pub.iaea.org/ books/iaeabooks/7648/IAEA-Safety-Glossary\#\#description [Accessed 10.06.2017]

International Atomic Energy Agency. (2009): IAEA Safety Standards: Classification of Radioactive Waste - No. GSG1. Available at: http://www-pub.iaea.org/books/IAEABooks/8154/Classification-of-Radioactive-Waste\#\#description [Accessed 10.06.2017]

Kernkraftwerk Stade. (2004): E. ON Kernkraft GmbH. Decommissioning and dismantlement of the Stade nuclear power plant - from nuclear power plant to green fields. Available at: https://www.eon.com/content/dam/eon-com/ de/downloads/unternehmenssuche/kernkraft-decommissioning_Stade_en.pdf [Accessed 20.012017]

Maggini, A., Ciolini, R., Pistelli, S., \& Garneri, E. (2016): Strategies and dismantling solutions for RPV internals of 
Trino NPP. Progress in Nuclear Energy, 93(27), 67-75. https://doi.org/10.1016/j.pnucene.2016.08.001

Nieves, L.A., Chen, S.Y., Kohout, E.J., Nabelssi, B., Tilbrook, R.W. \& Wilson, S.E. (1998): Analysis of disposition alternatives for radioactive contaminated scrap metal. Journal of the Franklin Institute 335 (6), 1089-1103.

Samseth, J. (2012): Closing and Decommissioning Nuclear Power Reactors. UNEP Year Book, 35-49.

Sanders, M. C., \& Sanders, C. E. (2016): A world's dilemma "upon which the sun never sets" - The nuclear waste management strategy (part I): Western European Nation States and the United States of America. Progress in Nuclear Energy, 90, 69-97.https://doi.org/10.1016/j.pnucene.2016.02.012

Slimak, A., \& Nečas, V. (2016): Melting of contaminated metallic materials in the process of the decommissioning of nuclear power plants. Progress in Nuclear Energy, 92, 2939. https://doi.org/10.1016/j.pnucene.2016.06.008

Tatranský, P., \& Nečas, V. (2009): Conditional release of materials from decommissioning process into the environment in the form of steel railway tracks. Nuclear Engineer- ing and Design, 239(6), 1155-1161. https://doi.org/ 10.1016/j.nucengdes.2009.02.013

Truelove, H. B., \& Greenberg, M. (2013): Who has become more open to nuclear power because of climate change? Climatic Change, 116(2), 389-409. http://doi.org/10.1007/ s10584-012-0497-2

Wei, H. J., Tsai, T. L., Wang, J. J., Chen, I. J., Wuu, J. L., \& Wang, T. W. (2009): Clearance measurement of metal scraps for nuclear facility at INER in Taiwan. Applied Radiation and Isotopes, 67(5), 944-949. https://doi.org/ 10.1016/j.apradiso.2009.01.080

World-nuclear.org. (2017): Decommissioning Nuclear Facilities. Available at: http://www.world-nuclear.org/information-library/nuclear-fuel-cycle/nuclear-wastes/decommissioning-nuclear-facilities.aspx [Accessed 25.01.2017]

Yuracko, K.L., Hadley, S.W., Perlack, R.D., Rivera, R.G., \& Curlee, T.R. (1997): Fernald's dilemma: Recycle the radioactively contaminated scrap metal, or bury it? Resources, Conservation and Recycling, 19(3), 187-198. https://doi. org/10.1016/S0921-3449(96)01188-3

\section{SAŽETAK}

\section{Gospodarenje otpadnim metalom i metode recikliranja u procesu razgradnje i demontaže nuklearnih elektrana}

Razgradnja i demontaža nuklearnih elektrana predstavljaju završnu fazu životnoga vijeka nuklearnih postrojenja te su sastavni dio djelotvorne kulture nuklearne sigurnosti. Dok neke zemlje provode izlazne nuklearne strategije, a druge planiraju izgradnju novih postrojenja ili produljuju životni vijek postojećima, razgradnja postrojenja neizbježna je. U radu se daje kratak pregled strategija i tehnika razgradnje i demontaže kao uvod u mogućnosti recikliranja i ponovne upotrebe radioaktivnoga metalnog otpada. Opće procjene upućuju na to da je većina otpada koji proizlazi iz razgradnje i demontaže radiološki materijal izuzet iz nadzora. Preostala je trećina radioaktivni materijal s različitim rasponom radioaktivnosti. Kako bi se recikliranje radioaktivnoga otpadnog metala prezentiralo u praksi, članak daje osvrt na procjenu količine otpadnoga metala koji proizlazi iz procesa razgradnje, korištenje topljenja kao moguće metode recikliranja (uključujući i sekundarni otpad) i aspekte utjecaja na okoliš i zdravlje. Također, dan je i primjer procesa razgradnje u tipu nuklearnoga postrojenja s vodenim reaktorom pod pritiskom, kao primjer konteksta buduće razgradnje Nuklearne elektrane Krško (NEK). Nakon razmatranja dostupnih podataka o gospodarenju otpadom nastalim razgradnjom i demontažom zaključak je da iako odluka o strategiji i tehnologiji razgradnje nije jednostavna, već jedinstvena za svaku zemlju, trenutačna iskustva daju važan uvid u kontekst složenosti i potencijala razgradnje te pružaju osnovu za buduće radnje.

\section{Ključne riječi}

nuklearne elektrane, razgradnja i demontaža, recikliranje metala, gospodarenje otpadom

\section{Author(s) contribution}

Ana Mostečak had the initial idea for the study, collected and interpreted data and wrote the first version of the article. Gordan Bedeković refined the idea for the study, performed a critical reading, review, and approval of the final paper version. 